Bull. Chem. Soc. Ethiop. 2012, 26(3), 361-372.

Printed in Ethiopia

ISSN 1011-3924

DOI: http://dx.doi.org/10.4314/bcse.v26i3.5

(C) 2012 Chemical Society of Ethiopia

\title{
FLUORIDE REMOVAL BY ADSORPTION ON THERMALLY TREATED LATERITIC SOILS
}

\author{
Kefyalew Gomoro, Feleke Zewge, Bernd Hundhammer and Negussie Megersa*
}

Department of Chemistry, Addis Ababa University, P. O. Box 1176, Addis Ababa, Ethiopia

(Received April 4, 2011; revised March 26, 2012)

\begin{abstract}
The ability of lateritic soils to remove fluoride from water has been studied. Important issues considered in the study include the relation between the mineral composition of soils and their ability to remove fluoride, the effect of thermal treatment of the soil on fluoride removal; the predominant fluoride containing species remain in the treated water and the possible mechanism of fluoride removal by lateritic soils. The fluoride removal capacity of thermally treated lateritic soils used in this study is in the range of 22 to $47 \mathrm{mmol} / \mathrm{kg}$. The maximum capacity of $47 \mathrm{mmol} / \mathrm{kg}$ was obtained for RGS fired at $500{ }^{\circ} \mathrm{C}$. The results obtained indicate that there is strong correlation between fluoride removal capacity and gibbsite content of the soil. From this it can be concluded that gibbsite is the active component in lateritic soils that strongly influence the fluoride removal capability. Speciation analysis reveals that at low initial fluoride concentrations the dissolution of gibbsite is facilitated by the adsorption of fluoride onto gibbsite. This may result in the formation of aluminum fluoro complexes in water.
\end{abstract}

KEY WORDS: Fluoride removal, Laterite soils, Speciation analysis, Adsorption capacity, Thermal treatment

\section{INTRODUCTION}

Fluoride ion exists in natural waters and it is an essential micronutrient in humans in preventing dental caries and in facilitating the mineralization of hard tissues, if taken at a recommended range of concentration. Higher level of fluoride in groundwater is a world-wide problem, which includes various countries from Africa and Asia as well as USA [1]. Ethiopia is among the most affected nations in Africa by the fluoride problem. Fluoride concentration, as high as $33 \mathrm{mg} / \mathrm{L}$, has been reported in drinking water sources in Ethiopia [1]. Excess fluoride in drinking water is prevalent in all of the Rift Valley regions of the country [2,3]. According to the Ministry of Water and Energy of Ethiopia, rural drinking water supply in the Rift Valley region is, to a large extent, dependent on groundwater [4, 5]. Hence, it becomes necessary to reduce the fluoride concentration within permissible limit of $1.5 \mathrm{mg} / \mathrm{L}$ according to the Ethiopian Standard for drinking water [4]. However, the Ministry of Water Resources on the basis of economic, practical and technical considerations proposed guideline for drinking water quality of fluoride at $3.0 \mathrm{mg} / \mathrm{L}$ [5]. The limit varies among countries and the age of people exposed. World Health Organization (WHO) has set a limit range between 0.5 and $1.5 \mathrm{mg} / \mathrm{L}$ [6]. After many years of use of drinking water from drilled wells in the Rift Valley, Ethiopia, dental and skeletal fluorosis has become a serious medical problem [2,3]. For communities in developing countries like the Rift Valley regions of Ethiopia where the groundwater is fluoride rich and provision of alternative water supply is difficult, treatment of contaminated water is the only option to provide safe drinking water.

Available techniques for the removal of fluoride belong to the following major categories: chemical precipitation [7, 8], membrane processes [9], adsorption by activated alumina [10, 11] ion exchange [12] and Nalgonda technique [13]. Nalgonda technique is also widely used in India because of its simplicity and cost effectiveness. However, the production of excess sludge is a concern. It is widely recognized that adsorption is an ideal and appropriate technique

*Corresponding author. E-mail: megersane@yahoo.com 
compared to other techniques, for small community water source defluoridation. The aspect of fluoride removal covering wider applications has also been reviewed by Mohapatra et al. [14].

In recent years, the use of low cost adsorbents has been investigated to remove fluoride from water. Such materials include: hydroxy apatite, calcite, fluorspar and quartz [15], fly ash [16], silica gel [17], bone char [18], spent catalyst [19], red mud [20] and bentonite [21]. Studies in Ethiopia as well as other developing countries indicated the possibility of using low cost adsorbents such as bone char, clay soils, diatomaceous earth, latertic soils and other related materials [22-28].

Different soil samples were collected from different parts of Ethiopia and were tested for their defluoridating capacities. The results show that soils can be used as alternatives for defluoridation purposes and the defluoridating capacities of the soil samples vary over a wide range [29]. Moges et al. [25] investigated the defluoridation of water by chips of clay pot and bricks. The investigation has shown that $120 \mathrm{~g}$ of each ground clay pot and brick removed $90 \%$ of $10 \mathrm{mg} / \mathrm{L}$ fluoride of $1 \mathrm{~L}$ water in a contact time of 180 hours while raw clay soil (not fired) showed a capacity of $72 \%$ under the same experimental conditions. This result indicates that firing is an important requirement to achieve better defluoridation. Similar studies indicated that the capacity of raw clay soils is low as compared to materials such as activated alumina [30, 31$]$. Zevenbergen et al. [32] have also investigated the fluoride removal capacity of Ando soils in Kenya. According to this study, the defluoridating capacity of the soil is $5.5 \mathrm{mg} / \mathrm{g}$. This value is higher compared to the capacity of ground clay and brick $(0.2 \mathrm{mg} / \mathrm{g})$, investigated by Moges $e t$ al. [25]. These soils are formed under tropical conditions of high rainfall and high temperature that is often seasonal.

The term laterite is used as a common name for iron oxide rich tropical soils, which have been formed under weathering of rocks under strongly oxidizing and leaching conditions that leads to the removal of silica, alkalis and alkaline earths. This process, referred to as laterisation, leads to an accumulation of sparingly soluble compounds as the more soluble constituents of the parent rocks are leached out. The mineral compositions of lateritic soils vary greatly depending on the stage of laterisation. Lateritic soils, even when silica poor, may contain clay minerals, iron oxide minerals (goethite, hematite) and hydrated oxide of aluminum (gibbsite). In the final stage of laterisation, bauxite is formed. Laterites differ from clay soils in that aluminum is present as oxides or hydroxides instead of silicates [33-35].

Although the adsorption capacity of the soils is low, their availability in large amounts and low costs make them potential candidates for the defluoridation in remote rural areas. It is important to compare the defluoridation ability of the soils with their chemical and mineralogical composition and also to understand the possible mechanisms of fluoride adsorption. The research works done so far have concentrated on the fluoride "removal capacity" of the soils based on total fluoride removed with no to conduct speciation analysis of the free fluoride and complexed fluoride. Thus, the purpose of this study was to determine the adsorption capacity of thermally treated lateritic soil and to analyze both free and complexed fluoride in the treated water. The measurement was carried out with and without the addition of TISAB for complexed and free fluoride, respectively. Selection of soil samples was mainly based on their abundance in large quantity in highlands near to the Ethiopian Rift Valley region where the fluoride content of groundwater is very high.

\section{EXPERIMENTAL}

\section{Sampling and sample preparation}

The soil samples for defluoridation experiments were collected from Adiss Ababa, Gullale, Burayyu Brick Factory compound and Ambo area $100 \mathrm{~km}$ west of Addis Ababa (5 km west of 
Ambo town on the road to Nekemt Town). Brick from Burayyu Brick Factory and clay pot obtained from market were tested in the same experiments. The soil samples are referred to as "red Gullale soil" (RGS), "yellow Gullale soil" (YGS), and "Ambo soil" (AS) in the following discussions. The soil samples were sun dried, crushed and sieved to obtain particle sizes between $0.17-0.32 \mathrm{~mm}$ prior to defluoridation experiments.

\section{Thermal treatment}

Twenty grams of RGS was transferred into a crucible and was then fired in a furnace (Carbolite, ELF model) at preset temperatures of 400, 500, 550, 600 and $800{ }^{\circ} \mathrm{C}$ for four hours. The temperature range was selected based on the previous screening test. At low temperature the clay soils are soft and cannot be used as filter medium on the field. But if the temperature is extremely high the clay minerals may exceed sintering point and cannot be useful for defluoridation purpose. At the end of four hours, the thermally treated soil sample was taken out of the furnace, kept in a desiccator and allowed to cool to room temperature and then weighed in order to determine the corresponding weight loss.

\section{Preparation of solutions}

A $0.1 \mathrm{M}$ NaF stock solution was prepared by dissolving $0.42 \mathrm{~g}$ of $\mathrm{NaF}$ (Riedel-de Haen, chem. pure) in distilled water. Other solutions, for calibration of the fluoride selective electrode were prepared from this stock solution by dilution with distilled water. In order to determine the extent of complexed fluoride in the samples, calibration and determination were carried out by addition of TISAB. TISAB was prepared by mixing $57 \mathrm{~mL}$ of glacial acetic acid, $58 \mathrm{~g}$ of sodium chloride, $7 \mathrm{~g}$ of sodium citrate, and $2 \mathrm{~g}$ of EDTA in volumetric flask and made to $500 \mathrm{~mL}$ with distilled-deionized water, and then the $\mathrm{pH}$ was adjusted to 5.3 with $6 \mathrm{M}$ sodium hydroxide, and then made up to $1000 \mathrm{~mL}$ in a volumetric flask with distilled-deionized water. Distilleddeionized water was used throughout the experiment for sample preparation, dilution, and rinsing apparatus prior to analysis [36, 37].

\section{Experimental procedures}

The fluoride ion selective electrode was calibrated prior to each experiment in order to determine the slope and intercept of the electrode. All experiments were carried out at a laboratory temperature of $21 \pm 3{ }^{\circ} \mathrm{C}$.

The defluoridation experiments were conducted at different contact times by adding $2 \mathrm{~g}$ of each adsorbent to $50 \mathrm{~mL}$ of aqueous fluoride solution of different concentrations. To study the fluoride adsorption capacity of different soils, $2 \mathrm{~g}$ of the respective soil were suspended in 50 $\mathrm{mL}$ of $0.99 \mathrm{mM}$ fluoride solution and the decrease in free fluoride concentration was monitored potentiometrically.

The same mass of the adsorbents and aqueous solution were used in all the experiments unless otherwise specified. The total fluoride ion concentration for calibration or for the defluoridation experiment was determined potentiometrically by adding $10 \mathrm{~mL}$ of the TISAB to $10 \mathrm{~mL}$ of the standard or sample solution. The complexed fluoride (CF) and the amount of fluoride removed $(\mathrm{RF})$ were determined using the following relations:

$\mathrm{CF}(\mathrm{mmol} / \mathrm{L})=\mathrm{TF}(\mathrm{mmol} / \mathrm{L})-\mathrm{FF}(\mathrm{mmol} / \mathrm{L})$

$\mathrm{IF}(\mathrm{mmol} . \mathrm{L})-\mathrm{TF}(\mathrm{mmol} / \mathrm{L})=\mathrm{RF}(\mathrm{mmol} / \mathrm{L})$

where IF is the initial fluoride, TF is total fluoride, FF is the free fluoride, and RF is the amount of removed fluoride. 
Analytical methods

The soil samples were characterized by X-ray diffraction (XRD) spectrometry and X-ray fluorescence (XRF) spectrometry at the University of Caliary, Italy and the University of Karlsuhe, Germany. The fluoride ion concentration was measured potentiometrically with the fluoride ion-selective electrode (Orion Combination fluoride electrode, model 96-09) and conductivity/pH meter (Jenway Model 4330). The $\mathrm{pH}$ of the solutions was determined potentiometrically by glass electrode.

\section{RESULTS AND DISCUSSION}

\section{Characterization of the soil samples}

The soil samples were analyzed by X-ray diffraction (XRD) and X-ray fluorescence (XRF) spectrometry and their corresponding chemical compositions are given in Table 1 . The results of XRD spectroscopic analysis of the soil samples show that all the samples contained quartz, which has hardly any defluoridating capacity. Essayas [38] has shown that coarse constituents of clay samples like quartz, mica, muscovite and microcline had no defluoridation capacity. If the amounts of $\mathrm{Fe}_{2} \mathrm{O}_{3}$ and $\mathrm{Al}_{2} \mathrm{O}_{3}$ are taken as an indication of the extent of laterisation of the soils, the RGS is the most lateritic soil and the extent of laterisation in AS and YGS is nearly the same.

Table 1. Mineral composition of the soil samples.

\begin{tabular}{|c|c|c|c|c|c|c|c|c|c|}
\hline Soil & $\begin{array}{c}\text { Quartz, } \\
\%\end{array}$ & $\begin{array}{c}\text { Feldspar, } \\
\%\end{array}$ & $\begin{array}{c}\text { Calcite, } \\
\%\end{array}$ & $\begin{array}{c}\text { Dolomite, } \\
\%\end{array}$ & $\begin{array}{c}\text { Illite, } \\
\%\end{array}$ & $\begin{array}{c}\text { Kaolinite, } \\
\%\end{array}$ & $\begin{array}{c}\text { Montmorillonite, } \\
\%\end{array}$ & $\begin{array}{c}\mathrm{Al}_{2} \mathrm{O}_{3}, \\
\%\end{array}$ & $\begin{array}{c}\mathrm{Fe}_{2} \mathrm{O}_{3}, \\
\%\end{array}$ \\
\hline AS & 22 & 7 & 3 & 5 & 12 & 9 & 30 & 3.1 & 7.8 \\
\hline YGS & 19 & 52 & 0 & 7 & 5 & $?$ & 5 & 5 & 6.23 \\
\hline RGS & 17 & 9 & 0 & 0 & 5 & $?$ & 31 & 22.68 & 13.09 \\
\hline
\end{tabular}

AS - Ambo Soil; YGS - Yellow Gullale Soil; RGS - Red Gullale Soil.

\section{Comparison of defluoridation capacity of untreated soil samples}

In this study it was intended to choose the soil with the highest fluoride removal capacity for further investigations. In order to classify the soils with respect to their defluoridation capacity, the amount of fluoride removed within the equilibration time of 4,000 s was measured. Results of the experiments are compiled in Table 2 .

The order $\mathrm{YGS} \cong \mathrm{AS}<\mathrm{RGS}$ was obtained with respect to the amount of fluoride adsorbed per gram of the soil. On the other hand, there is a significant difference in the amount of complexed fluoride in water between the soils and it is noticeable that there seems to be a correlation between fluoride adsorption and complexation of fluoride in water. The order observed for YGS, AS and RGS is well in line with the results of the mineral composition of the soils if it were assumed that the active components for fluoride adsorption are aluminum oxide and iron(III) oxide. Taking only these components into account, the active component in $2 \mathrm{~g}$ soil are about $0.2 \mathrm{~g}$ in YGS and AS but $0.7 \mathrm{~g}$ in RGS values which correlate fairly well with the adsorbed amount of fluoride. The high complexed fluoride concentration for RGS may be attributed to the presence of relatively high amount of $\mathrm{Al}_{2} \mathrm{O}_{3}$ which may dissolve in fluoride containing solution thereby releasing aluminum ion capable of complexing fluoride ions. As can be seen from the Table 2, the removal efficiencies of AS and YGS are too low for application to practical purposes. Due 
to this reason, further experiments were not conducted using these soil samples and only RGS was used in the subsequent studies.

Table 2. Effect of different adsorbing media on the removal capacity $(\mathrm{mmol} / \mathrm{kg}$ ) for the defluoridation of $0.99 \mathrm{mmol} / \mathrm{L}$ fluoride solution.

\begin{tabular}{|c|c|c|c|c|c|c|}
\hline Soil & $\begin{array}{c}\text { Initial } \\
\text { fluoride, } \\
\mathrm{mmol} / \mathrm{L}\end{array}$ & $\begin{array}{c}\text { Free } \\
\text { fluoride, } \\
\mathrm{mmol} / \mathrm{L}\end{array}$ & $\begin{array}{c}\text { Complexed } \\
\text { fluoride, } \\
\mathrm{mmol} / \mathrm{L}\end{array}$ & $\begin{array}{c}\text { Total fluoride } \\
\text { in water, } \\
\mathrm{mmol} / \mathrm{L}\end{array}$ & $\begin{array}{c}\text { Amount } \\
\text { adsorbed, } \\
\mathrm{mmol} / \mathrm{kg}\end{array}$ & $\begin{array}{c}\text { Final } \\
\mathrm{pH}\end{array}$ \\
\hline AS & 0.99 & 0.88 & 0.01 & 0.89 & 2.5 & 8.85 \\
\hline YGS & 0.99 & 0.75 & 0.15 & 0.90 & 2.3 & 5.69 \\
\hline RGS & 0.99 & 0.38 & 0.29 & 0.67 & 8.1 & 6.07 \\
\hline
\end{tabular}

The order YGS $\cong \mathrm{AS}<\mathrm{RGS}$ is obtained with respect to the amount of fluoride adsorbed.

\section{Effects of thermal treatment}

The purpose of the following experiments is to see the influence of thermal treatment on the removal efficiency and removal capacity of RGS. Two grams of each adsorbent was suspended in $50 \mathrm{~mL}$ of $0.99 \mathrm{mM}$ fluoride solution. The experiment was conducted over $65 \mathrm{~min}$, because this time was sufficient to reach equilibrium condition. The results of these experiments are summarized in Table 3.

Table 3. Effect of thermal treatment on percent removal efficiency and adsorption capacity ( $\mathrm{mmol} / \mathrm{kg}$ ) for the defluoridation of $0.99 \mathrm{mmol} / \mathrm{L}$ fluoride solution (last 2 columns).

\begin{tabular}{|c|c|c|c|c|c|}
\hline $\begin{array}{c}\text { Firing } \\
\text { temperature, }{ }^{\circ} \mathrm{C}\end{array}$ & $\begin{array}{c}\text { Free } \\
\text { fluoride, } \\
\mathrm{mmol} / \mathrm{L}\end{array}$ & $\begin{array}{c}\text { Complexed } \\
\text { fluoride, } \\
\mathrm{mmol} / \mathrm{L}\end{array}$ & $\begin{array}{c}\text { Total fluoride, } \\
\mathrm{mmol} / \mathrm{L}\end{array}$ & $\begin{array}{c}\text { Amount } \\
\text { adsorbed, } \\
\mathrm{mmol} / \mathrm{kg}\end{array}$ & $\begin{array}{c}\text { Percent } \\
\text { removed }\end{array}$ \\
\hline Untreated & 0.38 & 0.29 & 0.67 & 0.0081 & 32 \\
\hline 400 & 0.14 & 0.049 & 0.19 & 0.020 & 81 \\
\hline 500 & 0.078 & 0.26 & 0.34 & 0.016 & 66 \\
\hline 550 & 0.10 & 0.37 & 0.47 & 0.013 & 53 \\
\hline 600 & 0.16 & 0.34 & 0.50 & 0.012 & 49 \\
\hline 800 & 0.24 & 0.32 & 0.56 & 0.011 & 43 \\
\hline
\end{tabular}

As can be seen from Table 3, the highest removal efficiency and removal capacity was observed for the sample treated at $400{ }^{\circ} \mathrm{C}$ but further increase in temperature reduces the removal efficiency and removal capacity. The high removal capacity at $400{ }^{\circ} \mathrm{C}$ may be attributed to the removal of surface and constitutional water molecules and the removal of organic surface coatings, and surface impurities thereby increasing the surface area of the soil. The decline in the fluoride removal efficiency at higher treatment temperatures is probably caused by the change in the soil-mineral composition. At temperature above $700{ }^{\circ} \mathrm{C}$, clay minerals such as kaolinite, montmorillonite and illite lose all the constitutional $\mathrm{OH}$ and finally their layered structures are disrupted and can't be reconstituted by rehydration [39]. Both XRD and specific surface area should be measured to understand the change in composition and mineral structure. The percent removal and percent weight loss for RGS as a function of the firing temperatures are given in Figure 1 below.

The figure clearly shows that the highest removal efficiency was observed at $400{ }^{\circ} \mathrm{C}$. It can also be seen that the percent weight loss after $550{ }^{\circ} \mathrm{C}$ is more or less constant. This may be due to the removal of all constitutional water molecules at these temperatures. 


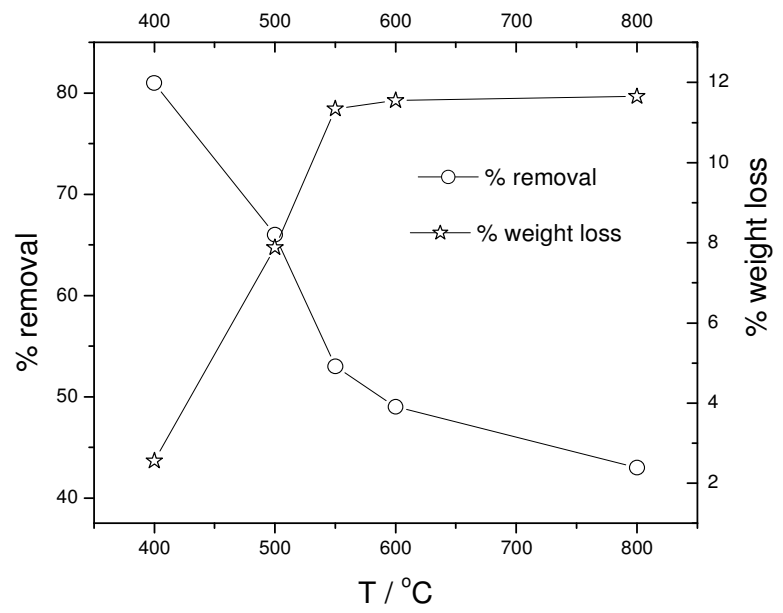

Figure 1. Percent removal and percent weight loss for RGS as a function of firing temperature.

Clays, fired at relatively lower temperatures, have long been used for making pot, bricks and other clay wares in different parts of Ethiopia. Since RGS could be used for the same purpose, comparative defluoridation study was carried out by using ground clay pot and brick as adsorbents. The removal efficiency and the amount of fluoride adsorbed per unit mass of each of the above adsorbents are given in Table 4. The table shows that removal efficiency of the adsorbents increases in the order untreated RGS, ground clay pot, ground brick and RGS fired at $500{ }^{\circ} \mathrm{C}$. It also shows that the fluoride removal efficiencies of ground clay pot and brick are greater than that of untreated RGS. This may indicate that thermal treatment at optimum temperature is important to enhance defluoridation efficiency.

Table 4. The removal efficiency and amount of fluoride adsorbed per $\mathrm{kg}$ of the adsorbent for defluoridation of $0.99 \mathrm{mM}$ fluoride solution by using $2 \mathrm{~g}$ of untreated RGS, RGS fired at $500{ }^{\circ} \mathrm{C}$, ground brick and clay pot.

\begin{tabular}{|c|c|c|c|c|c|c|}
\hline Adsorbent & $\begin{array}{c}\text { Initial } \\
\text { fluoride, } \\
\mathrm{mmol} / \mathrm{L}\end{array}$ & $\begin{array}{c}\text { Free } \\
\text { fluoride, } \\
\mathrm{mmol} / \mathrm{L}\end{array}$ & $\begin{array}{c}\text { Complexed } \\
\text { fluoride, } \\
\text { mmol/L }\end{array}$ & $\begin{array}{c}\text { Total } \\
\text { fluoride, } \\
\mathrm{mmol} / \mathrm{L}\end{array}$ & $\begin{array}{r}\text { Amount } \\
\text { adsorbed, } \\
\mathrm{mmol} / \mathrm{kg}\end{array}$ & $\begin{array}{l}\text { Percent } \\
\text { removed }\end{array}$ \\
\hline Untreated RGS & \multirow{4}{*}{0.99} & 0.38 & 0.29 & 0.67 & 8.1 & 32 \\
\hline RGS fired at $500{ }^{\circ} \mathrm{C}$ & & 0.078 & 0.26 & 0.34 & 16 & 66 \\
\hline Ground brick & & 0.12 & 0.28 & 0.40 & 15 & 60 \\
\hline Ground clay pot & & 0.34 & 0.29 & 0.63 & 9.1 & 36 \\
\hline
\end{tabular}

\section{Effect of initial fluoride concentration}

The effects of the initial fluoride concentrations on the adsorption of fluoride were studied by varying the initial fluoride concentrations in the range $0.99-3.85 \mathrm{mM}$ at a constant contact time and adsorbent dose. The adsorbents used in this study were untreated RGS, untreated HS, RGS fired at $500{ }^{\circ} \mathrm{C}$, ground clay pot and brick. $2 \mathrm{~g}$ of each adsorbent was used. The results obtained by using different adsorbents and different initial fluoride concentrations are presented in Table 5. As can be seen from Table 5, fluoride removal efficiency decreases with increasing initial fluoride concentration for a constant adsorbent dose and contact time. This is in accordance with the findings of Moges et al. [25] and Hussien [29]. The decrease in removal efficiency at 
higher initial fluoride concentrations is due to the saturation of the active sites of the adsorbent. However, the total capacity of the adsorbents increases when the initial fluoride concentration is increased. This can be attributed to the utilization of the less accessible or energetically less active sites because of increase in diffusivity and activity of fluoride ion upon increasing initial fluoride concentration. The interiors of the porous adsorbents contain more sites than exteriors. However, the sites present on the interior surface of a pore may not be as easily available as the sites on the exterior surface because of the resistance to the pore diffusion [40].

Table 5. Effect of initial fluoride concentration on the adsorption capacity and removal efficiency of different adsorbents.

\begin{tabular}{|c|c|c|c|c|c|c|}
\hline Adsorbent & $\begin{array}{c}\text { Initial } \\
\text { fluoride, } \\
\mathrm{mmol} / \mathrm{L}\end{array}$ & $\begin{array}{c}\text { Free } \\
\text { fluoride, } \\
\mathrm{mmol} / \mathrm{L}\end{array}$ & $\begin{array}{c}\text { Fluoride } \\
\text { complexed, } \\
\mathrm{mmol} / \mathrm{L}\end{array}$ & $\begin{array}{c}\text { Total } \\
\text { fluoride, } \\
\mathrm{mmol} / \mathrm{L}\end{array}$ & $\begin{array}{c}\text { Amount } \\
\text { adsorbed, } \\
\mathrm{mmol} / \mathrm{kg}\end{array}$ & $\begin{array}{c}\text { Percent } \\
\text { removed }\end{array}$ \\
\hline \multirow{2}{*}{$\begin{array}{c}\text { Untreated } \\
\text { RGS }\end{array}$} & 0.99 & 0.38 & 0.29 & 0.67 & 8.1 & 32 \\
\cline { 2 - 7 } & 1.96 & 0.84 & 0.55 & 1.4 & 15 & 29 \\
\cline { 2 - 7 } & 3.85 & 2.3 & 0.48 & 2.8 & 27 & 27 \\
\hline $\begin{array}{c}\text { RGS fired at } \\
500{ }^{\circ} \mathrm{C}\end{array}$ & 0.99 & 0.078 & 0.26 & 0.34 & 16 & 66 \\
\cline { 2 - 7 } & 1.96 & 0.33 & 0.39 & 0.72 & 32 & 63 \\
\cline { 2 - 7 } & 3.85 & 1.4 & 0.48 & 1.9 & 51 & 51 \\
\hline $\begin{array}{c}\text { Ground clay } \\
\text { pot }\end{array}$ & 0.99 & 0.34 & 0.26 & 0.59 & 10 & 40 \\
\cline { 2 - 7 } & 1.96 & 0.79 & 0.50 & 1.3 & 17 & 34 \\
\hline \multirow{2}{*}{$\begin{array}{c}\text { Ground } \\
\text { brick }\end{array}$} & 3.85 & 2.4 & 0.42 & 2.8 & 27 & 27 \\
\cline { 2 - 7 } & 0.99 & 0.12 & 0.28 & 0.40 & 15 & 61 \\
\cline { 2 - 7 } & 1.96 & 0.49 & 0.45 & 0.94 & 26 & 52 \\
\hline
\end{tabular}

\section{Effect of adsorbent mass}

The effect of adsorbent mass on the fluoride removal efficiency was studied by varying mass of the adsorbents, viz. 2, 4, 6 and $8 \mathrm{~g}$. The adsorbents investigated in this experiment were RGS fired at $500{ }^{\circ} \mathrm{C}$, ground clay pot and brick. The results obtained for different adsorbents and their respective different masses are shown in Table 6.

Table 6. Effect of adsorbent dose on removal efficiency and adsorption capacity for the defluoridation of $1.96 \mathrm{mM}$ fluoride solution by using RGS fired at $500{ }^{\circ} \mathrm{C}$, ground clay pot and ground bricks.

\begin{tabular}{|c|c|c|c|c|c|c|c|}
\hline $\begin{array}{c}\text { Adsor- } \\
\text { bent }\end{array}$ & $\begin{array}{c}\text { Mass of the } \\
\text { adsorbent, } \\
\mathrm{g}\end{array}$ & $\begin{array}{c}\text { Free } \\
\text { fluoride, } \\
\mathrm{mmol} / \mathrm{L}\end{array}$ & $\begin{array}{c}\text { Free } \\
\text { fluoride, } \\
\mathrm{mmol} / \mathrm{L}\end{array}$ & $\begin{array}{c}\text { Fluoride } \\
\text { complexed, } \\
\text { mmol/L }\end{array}$ & $\begin{array}{c}\text { Total } \\
\text { fluoride, } \\
\text { mmol/L }\end{array}$ & $\begin{array}{c}\text { Amount } \\
\text { adsorbed } \\
\mathrm{mmol} / \mathrm{kg}\end{array}$ & $\begin{array}{l}\text { Percent } \\
\text { removed }\end{array}$ \\
\hline \multirow{4}{*}{$\begin{array}{c}\text { RGS } \\
\text { fired at } \\
500{ }^{\circ} \mathrm{C}\end{array}$} & 2 & \multirow{12}{*}{1.96} & 0.33 & 0.39 & 0.72 & 32 & 63 \\
\hline & 4 & & 0.19 & 0.22 & 0.41 & 39 & 79 \\
\hline & 6 & & 0.086 & 0.13 & 0.22 & 44 & 89 \\
\hline & 8 & & 0.04 & 0.075 & 0.12 & 47 & 94 \\
\hline \multirow{4}{*}{$\begin{array}{l}\text { Ground } \\
\text { clay pot }\end{array}$} & 2 & & 0.79 & 0.29 & 1.1 & 22 & 44 \\
\hline & 4 & & 0.48 & 0.47 & 0.96 & 26 & 51 \\
\hline & 6 & & 0.27 & 0.41 & 0.68 & 33 & 65 \\
\hline & 8 & & 0.15 & 0.31 & 0.46 & 38 & 77 \\
\hline \multirow{4}{*}{$\begin{array}{l}\text { Ground } \\
\text { brick }\end{array}$} & 2 & & 0.49 & 0.45 & 0.94 & 26 & 52 \\
\hline & 4 & & 0.099 & 0.35 & 0.45 & 39 & 77 \\
\hline & 6 & & 0.043 & 0.31 & 0.35 & 41 & 82 \\
\hline & 8 & & 0.023 & 0.24 & 0.26 & 44 & 87 \\
\hline
\end{tabular}


The quantity of the adsorbent significantly influenced the extent of defluoridation as reflected by the measured residual fluoride concentration at equilibrium. Results in Table 6 show that the fluoride removal efficiency and adsorption capacity increase significantly with the adsorbent dose for a fixed initial fluoride concentration and contact time. This is due to an increase in active sites of the adsorbent with a corresponding increase in mass. The total fluoride ion concentration in the defluoridation of the above fluoride solution has decreased from $0.72 \mathrm{mM}(13.7 \mathrm{mg} / \mathrm{L})$ to $0.12 \mathrm{mmol} / \mathrm{L}(2.3 \mathrm{mg} / \mathrm{L})$ when the mass of RGS fired at $500{ }^{\circ} \mathrm{C}$ adsorbent was increased from $2 \mathrm{~g}$ to $8 \mathrm{~g}$. This suggests that it is possible to reduce the fluoride concentration in drinking water to a recommended value by further increasing the mass of the adsorbent.

\section{Effect of contact time}

The effect of contact time on fluoride removal was investigated by varying the contact time at a fixed initial fluoride concentration and adsorbent dose. The experiments were conducted by using $2 \mathrm{~g}$ of RGS fired at $500{ }^{\circ} \mathrm{C}$ as an adsorbent. The results of defluoridation carried out for contact time of 65, 130 and $200 \mathrm{~min}$ are summarized in Table 7.

Table 7. Effect of contact time on the fluoride removal efficiency for defluoridation of $1.96 \mathrm{mmol} / \mathrm{L}$ fluoride solution by using RGS fired at $500{ }^{\circ} \mathrm{C}$ as an adsorbent.

\begin{tabular}{|c|c|c|c|}
\hline $\begin{array}{c}\text { Initial fluoride } \\
\text { concentration, } \mathrm{mM}\end{array}$ & Contact time, $\mathrm{s}$ & $\begin{array}{c}\text { Total fluoride concentration, } \\
\mathrm{mM}\end{array}$ & Percent removed \\
\hline \multirow{2}{*}{$1.96 \times 10^{-3}$} & 4000 & 0.72 & 63 \\
\cline { 2 - 4 } & 8000 & 0.63 & 68 \\
\cline { 2 - 4 } & 12000 & 0.57 & 71 \\
\hline
\end{tabular}

Results of Table 7 show that fluoride removal efficiency increases with an increase in contact time. However, the increase was not significant for longer contact times. This indicates that longer contact time has less significance since the reaction is fast during the initial minutes. Allowing more time does not bring a gain in fluoride uptake by the media, if any then not significant. It was also noted that the efficiency is high at low fluoride concentration and decreases with increasing fluoride concentration irrespective of the contact time. Results of all the tables presented so far indicated that certain amount of fluoride ion remains in water by forming complex with metal cations.

Defluoridation experiments were also carried out over a long time by shaking the fluorideRGS soil mixture for $72 \mathrm{~h}$ using a flask shaker (Gallenkamp). In these experiments, $2 \mathrm{~g}$ of the RGS were added to $50 \mathrm{~mL}$ fluoride solution of the initial concentrations indicated in Table 8 . The results obtained are compiled in Table 8 and the corresponding adsorption isotherm is depicted in Figure 2.

Table 8. Results of defluoridation experiment conducted for $72 \mathrm{~h}$ using RGS treated at $500{ }^{\circ} \mathrm{C}$.

\begin{tabular}{|c|c|c|c|c|c|}
\hline $\begin{array}{c}\text { Contact } \\
\text { time }\end{array}$ & $\begin{array}{c}\text { Initial fluoride, } \\
\mathrm{mmol} / \mathrm{L}\end{array}$ & $\begin{array}{c}\text { Free fluoride } \\
\mathrm{mmol} / \mathrm{L}\end{array}$ & $\begin{array}{c}\text { Complexed } \\
\text { fluoride, } \\
\mathrm{mmol} / \mathrm{L}\end{array}$ & $\begin{array}{c}\text { Total fluoride, } \\
\mathrm{mmol} / \mathrm{L}\end{array}$ & $\begin{array}{c}\text { Amount } \\
\text { adsorbed, } \\
\mathrm{mmol} / \mathrm{kg}\end{array}$ \\
\hline \multirow{3}{*}{$72 \mathrm{~h}$} & 0.99 & 0.31 & 0.51 & 0.82 & 4.3 \\
\cline { 2 - 6 } & 1.96 & 0.84 & 0.45 & 1.3 & 17 \\
\cline { 2 - 6 } & 3.85 & 1.9 & 0.83 & 2.7 & 27 \\
\cline { 2 - 6 } & 5.66 & 3.0 & 1.7 & 4.7 & 25 \\
\cline { 2 - 6 } & 7.41 & 4.0 & 1.2 & 5.2 & 59 \\
\hline
\end{tabular}

Bull. Chem. Soc. Ethiop. 2012, 26(3) 


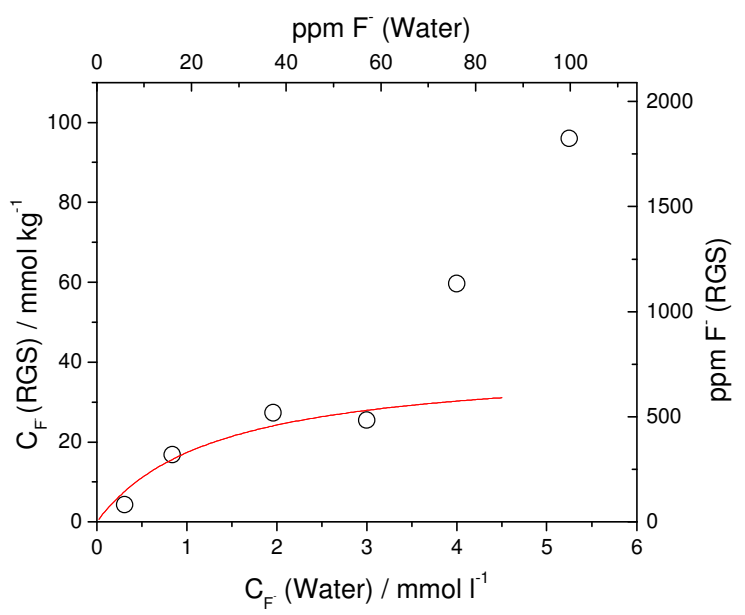

Figure 2. Adsorption isotherm obtained after $72 \mathrm{~h}$ contact time defluoridation using RGS treated at $500{ }^{\circ} \mathrm{C}$.

The experimental data were fit with Langmuir isotherm model. As can be seen from Table 8 and Figure 2, the amount of fluoride-adsorbed increases markedly for free fluoride concentration greater than $3.0 \mathrm{mmol} / \mathrm{L}$. This may be attributed to the formation of stable aluminum-fluoride complexes at higher free fluoride concentrations that may be removed by being adsorbed on the soil. As can be seen from results of Table 8 , the complexed fluoride concentration decreases with an increase in the free fluoride concentration. This may also indicate that some of the stable fluoride complexes formed at higher free fluoride concentrations are removed by adsorption on the soil.

Kau et al. [41], in their investigation to evaluate the potential effectiveness of kaolin clay liners, has also observed a similar phenomenon. They explained this observation on the basis of a site activation process, which may occur during the fluoride removal. This is a process in which the initially adsorbed fluoride ions are supposed to create additional spaces for the other incoming fluoride ions. However, they have no experimental proof for their explanation as the subsequent X-ray analysis of the fluoride contaminated clay showed no detectable sign of any kaolin structural damage.

The relationship among free, complexed and total fluoride for $72 \mathrm{~h}$ defluoridation is clearly shown in Figure 3 below. As can be seen from Figure 3, the amount of fluoride complexed increases with an increase in free fluoride concentration as expected and reach a maximum. Then it starts to decline with further increase in free fluoride concentration and as the amount of fluoride adsorbed increases. This may also imply that the stable aluminum fluoride complexes formed at higher concentrations might have been removed by adsorption on the soil which still needs further study

\section{Kinetics of fluoride removal}

In most of the experiments, the time dependence of the decrease in fluoride concentration has been studied. The results obtained can be used as a clue to elucidate the kinetics of fluoride removal and draw conclusion about the mechanism of the defluoridation process. The way the experiments were performed has to be taken into consideration in order to avoid pitfall in the interpretation of the experimental results. Since the dry soil is added to a stirred solution of 
known fluoride concentration, the soil particles were suspended in the solution within the first few seconds of the experiments. In this process, the soil particles are moistened and water layers will be adsorbed at their surfaces and soluble constituents will dissolve. Simultaneously, fluoride ions are brought in contact with the adsorption sites on the soil particle surface and fluoride adsorption onto the adsorption sites will occur creating a concentration gradient between bulk solution and surface of the "active" soil particles. Assuming that the rate of adsorption is fast compared to the diffusion of fluoride and with further assumption that the radial velocity of the heavier soil particles is less than that of the aqueous solution, the flux of fluoride to the surface of "active" soil particles is restricted by the concentration difference between the bulk and the particle surface and the thickness of the stagnant water layer adherent to the particle. Even this is a rather simple model for the real system; it may be used as a zero approximation to explain experimental results.

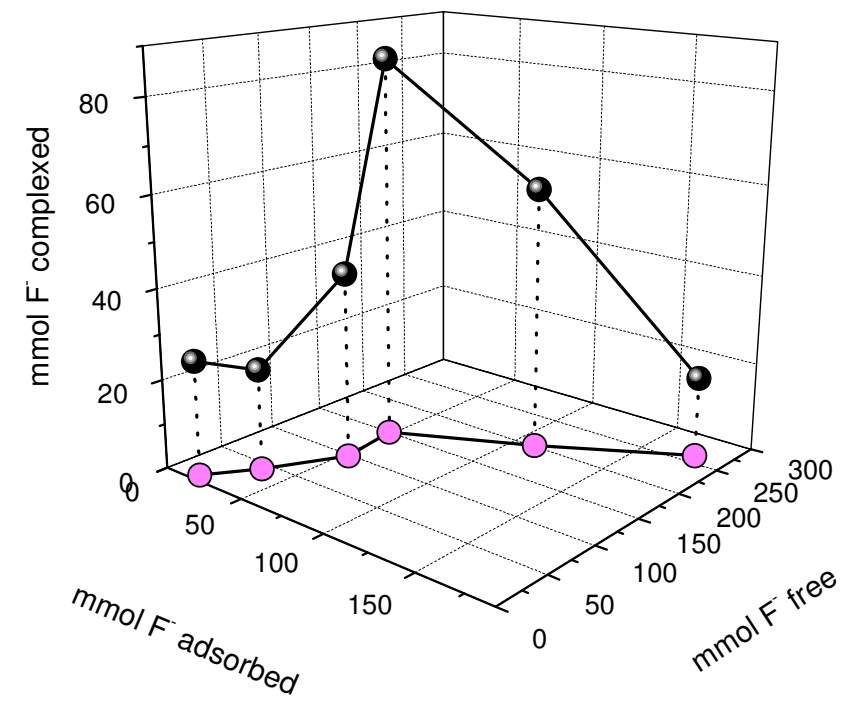

Figure 3. Three dimensional Langmuir isotherm for $72 \mathrm{~h}$ defluoridation of fluoride solutions using RGS treated at $500{ }^{\circ} \mathrm{C}$.

Fitting of the concentration-time curve with a theoretically reasonable function should yield some information about mechanism of fluoride removal. As expected from the above arguments about the diffusion control of the process, the best fits were obtained by utilizing non-linear fitting with an exponential decay function. Fitting of the experimental data with exponential decay function of the second order gave the following equation for change of concentration as a function of time:

$C(t)=C_{o}+C_{1} \exp \left[-k_{1} t\right]+C_{2} \exp \left[-k_{2} t\right]$

where $\mathrm{C}(\mathrm{t})$ is concentration of fluoride at time, $\mathrm{t} ; \mathrm{C}_{\mathrm{o}}$ is the concentration of fluoride at infinite time; $\mathrm{C}_{1}$ and $\mathrm{C}_{2}$ are constants having concentration units while $\mathrm{k}_{1}$ and $\mathrm{k}_{2}$ are rate constants. Values of these constants for the defluoridation of $1.96 \mathrm{mmol} / \mathrm{L}$ fluoride solution by RGS are given in Table 9.

The presence of two exponential terms, with two different rate constants, in equation (3) may indicate that the removal of fluoride by the soil involves two mechanisms: an initial rapid adsorption followed by slower uptake as can be seen from the two rate constants, $\mathrm{k}_{1}$ and $\mathrm{k}_{2}$. Besides the adsorption at the outer surface of the adsorbent, the adsorbate molecules may 
diffuse into the interior of the adsorbent. The first rate constant, $\mathrm{k}_{1}$, takes into account not only the fluoride removal but also wetting of the soil particles. Thus, it seems that the second process mainly determines the fluoride removal.

Table 9. Values of $\mathrm{C}_{\mathrm{o}}, \mathrm{C}_{1}, \mathrm{C}_{2}, \mathrm{k}_{1}$ and $\mathrm{k}_{2}$ obtained by fitting the experimental data to this function for defluoridation of $1.96 \mathrm{mM}$ fluoride solution by using $2 \mathrm{~g}$ of untreated RGS and RGS fired at different temperatures.

\begin{tabular}{|c|c|c|c|c|c|}
\hline Firing temp., ${ }^{\circ} \mathrm{C}$ & $\mathrm{C}_{\mathrm{o}}$ & $\mathrm{C}_{1}$, & $\mathrm{C}_{2}$ & $\mathrm{k}_{1}\left(\mathrm{~s}^{-1}\right)$ & $\mathrm{k}_{2}\left(\mathrm{~s}^{-1}\right)$ \\
\hline Untreated & 0.0008 & 0.00033 & 0.00107 & $2.9 \times 10^{-2}$ & $4.7 \times 10^{-4}$ \\
\hline 400 & 0.00053 & 0.00064 & 0.00078 & $1.8 \times 10^{-2}$ & $6.4 \times 10^{-4}$ \\
\hline 500 & 0.00032 & 0.00053 & 0.00119 & $3.5 \times 10^{-2}$ & $7.7 \times 10^{-4}$ \\
\hline 550 & $4.1 \times 10^{-4}$ & 0.0017 & $4.91 \times 10^{-4}$ & $2.8 \times 10^{-2}$ & $7.1 \times 10^{-4}$ \\
\hline 600 & 0.00048 & 0.001 & 0.00044 & $2.7 \times 10^{-2}$ & $7.6 \times 10^{-4}$ \\
\hline 800 & $6.8 \times 10^{-4}$ & $6.4 \times 10^{-4}$ & $4.4 \times 10^{-4}$ & $1.0 \times 10^{-2}$ & $3.2 \times 10^{-4}$ \\
\hline
\end{tabular}

\section{CONCLUSIONS}

Results of XRD and XRF spectroscopic analysis of the soil samples revealed that all the samples contained quartz, which has hardly any defluoridating capacity. Investigations of the defluoridating capacity of the soil samples have shown considerable difference in their defluoridating capacity. This is due to differences in their mineral compositions. RGS with a large iron oxide and aluminum oxide contents was found to exhibit the highest removal capacity. A series of defluoridation experiments conducted showed that the amount of fluoride removed is affected by factors like initial fluoride concentration, adsorbent dose and contact time. The study has also indicated that certain quantity of fluoride remains in water by forming complexes with metal cation like aluminum from the soil.

The amount of fluoride adsorbed per mass of the adsorbent was found to increase markedly with an increase in initial fluoride concentration in the solution and mass of each adsorption medium. This may be attributed to the formation of stable aluminum fluoride complexes at high initial fluoride concentration, which could be removed by being adsorbed by the soil. Study of kinetics of fluoride removal by the different soil samples indicated that fluoride removal by the soil samples involves two mechanisms with different rate constants: an initial rapid adsorption of fluoride on the surface of the adsorbent followed by slower diffusion of the fluoride into the interior of the adsorbent. Firing an adsorbent at optimum temperature can significantly increase its defluoridating capacity.

\section{ACKNOWLEDGEMENTS}

The authors greatly acknowledge Dr. Alessandiro Revaldino, University of Caliary, Italy and Dr. Utz Karmar, University of Karlsruhe, Germany for carrying out XRD and XRF analyses of the soil samples, and Department of Chemistry, Addis Ababa University for providing laboratory facilities.

\section{REFERENCES}

1. Reimann, C.; Bjorvatn, K.; Frengsta, K. B.; Melaku, Z.; Tekle Haimanot, R.; Siewers, U. Sci. Tot. Environ. 2003, 311, 65.

2. Kloos, H.; Tekle Haimanot, R. Trop. Med. Int. Health 1999, 4, 355.

3. Tekle Haimanot, R.; Kloos, H.; Reimann, C.; Fantaye, W.; Zerihun, L.; Bjorvatn, K. Sci. Tot. Environ. 2006, 3679, 182.

4. Federal Democratic Republic of Ethiopia, Ethiopian Quality and Standard Authority Guidelines for drinking water quality, Addis Ababa, 2001.

5. Federal Democratic Republic of Ethiopia, Ministry of Water Resources, Ethiopia Guidelines Specification for Drinking Water Quality, Addis Ababa, 2002. 
6. WHO, Guidelines for Drinking-Water Quality, 3rd ed., Vol. 1, Recommendations, 2006.

7. Saha, S. Water Res. 1993, 27, 1347.

8. Parthasarathy, N.; Buffle, J.; Haerdi, W. Water Res. 1986, 20, 443.

9. Pervov, A.G.; Dudkin, E.V.; Sidorenko, O.A.; Antipov, V.V.; Khakhanov, S.A; Makarov, R.I. Desalination 2000, 132, 315.

10. Ghorai, S.; Pant, K.K. Sep. Purif. Technol. 2005, 42, 265.

11. Meenakshi, R. C.; Maheshwari, J. Hazard. Mater. 2006, 137, 456.

12. Qureshi, S.Z.; Khan, M.A.; Rahman, N. Wat. Treatment 1995, 10, 307.

13. Drost, R.L. in Theory and Practice of Water and Waste Water Treatment, Wiley: New York; 1997.

14. Sujana, M.G.; Pradhan, H.K.; Anand, S. J. Hazard. Mater. 2009, 161, 120.

15. Fan, X.; Parker, D.J.; Smith, M.D. Water Res. 2003, 37, 4929.

16. Chaturvedi, A.K.; Yadava, K.P.; Pathak, K.C.; Singh, V.N. Water, Air Soil Pollut. 1990, 49, 51.

17. Wang, R.; Li, H.; Na, P.; Wang, Y. Water Qual. Res. J. Can. 1995, 30, 81.

18. Bhargava, D.S.; Killedar, D.J. Water Res. 1992, 26, 781.

19. Lai, Y.D.; Liu, J.C. Sep. Sci. Technol. 1996, 31, 2791.

20. Cengeloglu, Y.; Kir, E.; Ersoz, M. Sep. Purif. Technol. 2002, 28, 81.

21. Srimurali, M.; Pragathi, A.; Karthikeyan, J. Environ. Pollut. 1998, 99, 285.

22.Veressinina, Y.; Trapido, M.; Ahelik, V.; Munter, R. Proc. Est. Acad. Sci. 2001, 81.

23. Dahi, E.; Mtalo, F.; Njau, B.; Bregnhj, H. Proceedings of 22nd WEDC Conference, New Delhi, India, 1996.

24. Shimelis, B.; Zewge F.; Chandravanshi, B.S. Bull. Chem. Soc. Ethiop. 2006, 20, 17.

25. Moges, G.; Zewge, F.; Socher, M. J. Afr. Earth Sci. 1996, 21, 479.

26. Shewangzaw, D. M.Sc. Thesis, Addis Ababa University, Addis Ababa, Ethiopia, 1998.

27. Bjorvatn, K.; Reimann, C.; Siren, H.; Tekle Haimanot, R.; Melaku, Z.; Siewwrs, U. Oral Health Prev. Dent. 2003, 1, 141.

28. Zewge, F. Solution: A Biannual Newsletter of the Chemical Society of Ethiopia 2005, 14, 15 .

29. Husien. I. M.Sc. Thesis, Addiss Ababa University, Addis Ababa, Ethiopia, 1999.

30. Bulusu, K.R.; Sundaresan, B.B. J. Environ. Eng. 1979, 60, 1.

31. Commis, B.T. Control of Excessive Fluoride Levels for Small Community Water Supplies with Particular Reference to Developing Countries: an interim brief Report, Maidenhead, England, personal communication, 1990.

32. Zevenbergen, C.; Reeuwijk, L.P.V.; Frapporti, G.; Louws, R.J.; Schuiling, R.D. Sci. Tot. Environ. 1996, 188, 225.

33. Goldich, S.S. Encyclopedia of Science and Technology, Vol. 9, 7th ed., McGraw-Hill Inc.: New York; 1992; p 630.

34. Norton, B.T.; Esposito, J.J. The New Encyclopedia of Britannica, Vol. 7, 15th ed., Encyclopedia Britannica Inc.: Chicago; 1995; p 179.

35. Staley, M.; Tatlow, J.C.; Sharpe, A.G. Advances in Fluorine Chemistry, Butterworths: London; 1961; p 35.

36. Bailey, P.L. Analysis with Ion- selective Electrodes, 3rd ed., Heiden: London; 1980.

37. Koryata, J. Ion-selective Electrodes, Cambridge University Press: London; 1975, p 102.

38. Essayas, A. M. Sc. Thesis, Addis Ababa University, Addis Ababa, Ethiopia, 2002.

39. Grim, R.E. Clay Mineralogy, McGraw-Hill: New York; 1968.

40. Choi, W.W.; Chen, Y.K. J. Am. Water Works Assoc. 1979, 71, 562.

41. Kau, P.M.H; Binning, P.J.; Hitchock, P.W.; Smith, D.W. J. Contam. Hydrol. 1999, 36, 131. 